\title{
The Nairobi Code for Communication on Environment and Development*
}

This Code has been prepared as a guide for members of the International Public Relations Association (IPRA) for areas of practice related to the environment.

1. IPRA Members accept that they have a responsibility to ensure that the information and counsel which they provide, and products or services which they promote, fall within the context of sustainable development.

2. Members shall endeavour to encourage their organizations, companies, or clients, to adopt policies which recognize that careless use of resources and disregard for the environment can lead to severe limitations on economic growth, grave social disruption, and serious health hazards.

3. Members shall, wherever appropriate, counsel their companies, clients, or organizations, to undertake regular environmental assessments of products and operations, and to produce and communicate environmental codes of practice or guidelines for their employees and other publics.

4. Members shall not publicize or promote products, organizations, or services, as having environmental benefit unless these benefits are demonstrable in the light of current science and [other] knowledge.

5. Members shall endeavour at all times to promote openness and dialogue which fairly handles both facts and concerns related to the environment and development.

6. Members shall not seek to raise or respond to unrealistic environmental expectations but shall generally support organizations, products, or services, which are provably taking steps to improve environmental performance in a time-scale which takes account of community concerns and government requirements as well as technological and economic constraints.

7. Members shall seek to develop programmes which counsel and communicate on the benefit of a balanced consideration of environmental, economic, and social, development factors.

8. Members shall provide a free flow of information within and through IPRA concerning environmental and development issues on an international level.

9. Members should be familiar with, and encourage, the organizations they work for to support, and abide by, Codes of Practice of other internationally recognized organizations such as the United Nations and International Chamber of Commerce.

* Adopted by the International Public Relations Association (IPRA) Council Meeting in Nairobi, Kenya, November 1991.

$\dagger$ Evidently in this case meaning global. - Ed.

\section{Geneva to Host Biodiversity Convention Secretariat}

$\mathrm{F}^{\mathrm{s}}$ ollowing discussions very late last year with Secretary-General Boutros Boutros-Ghali, the then Executive Director of the United Nations Environment Programme (UNEP), Dr Mostafa K. Tolba, announced that the interim secretariat for the Framework Convention on the Conservation of Biological Diversity would be located in Geneva.

The Convention was agreed to in May 1992 in Nairobi after nearly four years of negotiations under UNEP auspices. It was presented in June 1992 to the United Nations Conference on Environment and Development (UNCED) in Rio de Janeiro for signature by Governments. So far, more than 150 States have signed the Convention.

According to article 40 of the treaty, UNEP's Exe- cutive Director is to provide the interim secretariat for the Convention until the first meeting of its parties. This will be convened within one year of the Convention's entry into force, upon ratification by 30 countries.

UNEP has also concluded an agreement with the appropriate Swiss authorities to concentrate all UNEP offices based in Switzerland in the Geneva Executive Centre. Accordingly, the interim secretariat for the Convention on Diversity will be located in that building, when once it is ready for occupation.

United NATIONS OfFICE IN GENEVA
Palais des Nations
1211 Geneva 10
Switzerland.

\section{Field Studies Council*}

$\mathrm{T}$ his year is a very special, jubilee, one for the Field Studies Council (FSC) of Great Britain, for on 10 December 1943, in the Natural History Museum, South Kensington, London, a group of distinguished biologists and other academics met together to form the 'Council for the Promotion of Field Studies'. The object of the Council was to encourage the study of the environment and living things in the environment itself. As a result of that meeting the Council's first field centre, Flatford Mill, was established in 1946.

Today the FSC is an independent educational charity and manages a network of 11 field centres in England and

* Adapted from Naturopa Environment Features, Centre Naturopa, Council of Europe, BP 431 R6, F-67006 Strasbourg Cedex, France. - Ed.
Wales which together take over 35,000 students a year on a variety of environmental education courses. It also engages in other activities in an effort to achieve its ambitious mission statement of 'Environmental understanding for all'. Perhaps the most important of these is the publication of educational resources, including the well-known 'AIDGAP' keys to animals and plants, and environmental consultancy for local and national government as well as the business community.

\section{For School-age Students}

Nearly all the courses for schoolchildren at FSC centres are closely related to the demands of the school curriculum. For students aged 5-16, following the new national curriculum in England and Wales, both 'geo- 
graphy' and 'science' have some field-work requirements and there are also plenty of opportunities for teachers to use out-of-classroom experiences to deliver aspects of other subjects. For older students, Advanced Level courses also have a substantial field-work component. Schoolteachers usually negotiate the content of a course with one of the tutors at a field-centre, and courses can last anything from a day to a week, with older students usually taking part in the longer courses.

Most FSC centres can take between 75 to 100 students at a time on a residential course. They have fully equipped laboratories and libraries, but their most important resource is enthusiastic tutors who carry out most of the teaching.

The Field Studies Council is not a campaigning organization - the main objective of most courses is to enable students, through first-hand experience, to understand the physical, biological, and human, processes at work in the environment. All courses include elements of awarenessraising, knowledge, understanding, first-hand investigation, and decision-making. The FSC's aspiration is that, equipped in this way, students will be able to make rational decisions about environmental issues, and that these decisions will lead to individual commitment and generate personal, group, and organizational, action.

\section{For Adults}

Although three-fifths of its customers are schoolchildren, the FSC also runs a substantial number of courses for adults. These include courses for teachers and fellow professionals in business and government administration. Courses for teachers are designed to transfer skills and knowledge, and to empower them to undertake their own field-work. Over the last 12 months, FSC courses for both United Kingdom and European businesses have focused on environmental awareness and environmental auditing; in short putting the environment into the business plan. The FSC's general-interest environment courses cover a variety of themes and are run from its centres in England and Wales as well as from overseas locations.

Obviously the 'for all' aspect of the FSC's mission statement is impossible to achieve simply through field centres; consequently it publishes a range of environmental materials to reach a wider audience. Publications range from the well-known AIDGAP identification guides to a new series for 14-16 year-olds which encourage them to investigate a range of environmental issues at first hand. Other publications include an annual journal, 'Field Studies', a research summary series edited jointly with the British Ecological Society, and materials for the Open University ecology course.

The FSC is also engaged in research on a number of scales. Most of the centres undertake a variety of smallscale research projects ranging from grassland plant research at Nettlecombe Court to an investigation into the relative cost of low-energy light-bulbs at Orielton. The FSC's research, training, and consultancy arm, FSCRC, incorporating the Oil Pollution Research Unit, carries out a wide range of contracts to examine the environmental impact of industrial operations. Work has focused mainly on marine and freshwater habitats, but recently has extended to mine reclamation sites and the environmental impact of proposed business development. Henry Disney, an FSC Research Fellow at Cambridge University, to- gether with Paul Moxey, based in Epping Forest, constitute the third arm of the FSC's research operations.

\section{Lobbying Activities and Future}

The FSC also believes in lobbying for environmental education and ensuring that out-of-classroom activities remain an opportunity in the curriculum. There are many threats and challenges in the UK, as both the content and the structure of the curriculum, together with the school management and organization, undergo change and reform. Many field-centres, managed by local education authorities for example, are under threat of closure. Being involved in curriculum development and innovation is also important. Currently, the FSC is involved with Imperial Chemical Industries (ICI) to produce curriculum materials which will enable students to investigate the relationship between an industry, the local community, and the environment.

So much for the present work of the FSC in England and Wales; what of its future, as it does not want to stand still! The objectives that the organization has set itself over the next five years are to:

- Maintain the ambience or special character of an FSC experience by providing a 'quality' service;

- Ensure that fun and enjoyment go hand-in-hand with rigour and scholarship;

- Continue to pioneer within the field of environmental education and out-of-classroom activity both within and outside the United Kingdom;

- Create partnerships which allow the FSC to broaden the base of its expertise and make contact with a wider spectrum of groups and individuals;

- Achieve financial targets which allow investments in people and property; and

- Increase the FSC's ability to 'green' its own business as well as assisting others to 'green' theirs.

The FSC also has a wider vision for Continental Europe. Having always had links with environmental educationalists in other European countries, it has recently, through sponsorship by British Petroleum, the UK government's Know How Fund, and the British Council, developed close relationships with environmental educationalists in central Europe. In 1993, the FSC hopes to be able to host a conference which will act as a starting-point for the development of a networking process for field centres across Europe, enabling those involved in environmental education through out-of-classroom activities to share experiences, enthusiasm, and expertise. As the FSC looks to the next 50 years, it hopes that it will be part of a 'close Europe' in which all students have the entitlement and opportunity of environmental understanding for all' through first-hand experience.

Details about the FSC, its 50th anniversary celebrations, and/or the 1993 Conference, may be obtained from the undersigned:

\author{
JAMES HINDSON \\ Field Studies Council \\ Central Services \\ Preston Montford \\ Montford Bridge \\ Shrewsbury SY1 IHW \\ England, UK.
}

